\title{
The State and Social Capital: An Institutional Theory of Generalized Trust
}

\author{
Bo Rothstein \\ Department of Political Science \\ Göteborg University \\ SE-405 30 Göteborg \\ Sweden \\ Bo.Rothstein@pol.gu.se
}

\&

Department of Political Science
McGill University
Montréal, Québec H3A 2T7
Canada
Dietlind.Stolle@mcgill.ca

Accepted for publication in Comparative Politics

Authors' names are in alphabetical order and they share equal responsibility for the article 


\begin{abstract}
The purpose of this article is to present an alternative theory on the generation of social capital. In the discussion about the sources of social capital it has been stressed that generalized trust is built up by the citizens themselves through a culture that permeates the networks and organizations of civil society. Since this approach has run into conceptual problems and has produced only mixed empirical evidence, we like to highlight instead how social capital is embedded in and linked to formal political and legal institutions. Not all political institutions matter equally, however. In fact, we argue that trust thrives most in societies with effective, impartial and fair street-level bureaucracies. The article presents the causal mechanism between these institutional characteristics and generalized trust, and illustrates its validity in a crossnational context.
\end{abstract}




\section{Introduction: The Theory of Social Capital}

The purpose of this article is to present a new theory explaining how social capital is generated. The reason for investigating this is the wealth of empirical research showing that social capital is associated with a number of political, social, and economic outcomes that for most people are normatively desirable. Among these are well-performing democratic institutions (Putnam 1993, Newton 1999b, Woolcook 2001), personal happiness (Helliwell 2002), optimism and tolerance (Uslaner 2002), economic growth (Knack \& Keefer 1997, Zak \& Knack 2001), and democratic stability (Inglehart 1999). The problem is that in this abundance of positive associations between social capital and various desired social and political outcomes, the sources of social capital often remain under-theorized and empirically unexplored. Simply put, if social capital is such an important societal resource, we need to know more about how it is generated and maintained.

Social capital has been defined as generalized trust, access to and membership in various types of networks, as well as norms of reciprocity (Coleman 1990; Putnam 1993). We consider the attitudinal aspects of the concept, such as generalized interpersonal trust, to be the most important part of social capital. The reason is that individuals can be members of networks that consist of untrustworthy agents, which play a destructive role for the values listed above. For example, such networks can be held together by distrusting agents that are outside the network. There is thus no logical reason why membership in networks per se should be a desired social value. Attitudes of generalized trust extend beyond the boundaries of face-to-face interaction and incorporate people who are not personally known (Stolle 2002). 
That citizens in some countries, regions, cities or villages are able to trust each other and thereby solve many of their collective action problems while others are not, turns out to be one of the most interesting puzzles in the social sciences (Ostrom 1990; Krishna 2002). In this article we

will address this particular issue in more detail, and sketch out a theory of the formation of generalized trust that is embedded in the structure and characteristics of political institutions. In fact we argue that many of the effects that social capital has been shown to have on institutions might be as much caused by the effects of institutional differences on social capital. Thus, our ambition is to present a theory in which the causal logic that has been the "established wisdom" in most studies of social capital, is reversed.

\section{The Generation of Social Capital— The Society-Centered Model}

The social capital literature is divided on the question of the causes and origins of social capital. On the one side are scholars who argue that variations in the amount and type of social capital can be explained primarily by society-centered approaches (Fukuyama 1999; Putnam 2000). In this Tocquevillian approach, the capacity of a society to produce social capital among its citizens is determined by its long-term experience of social organization, anchored in historical and cultural experiences that can be traced back over very long periods. The societycentered approach views regular social interaction, preferably through membership in voluntary associations, as the most important mechanism for the generation of social capital. Following the Tocquevillian tradition, formal and informal associations and networks are seen as creators of social capital because of their socializing effects on democratic and cooperative values and norms. 
A number of studies carried out in different democratic countries over the last few years have called into question the effect of participation in many voluntary associations directed at benevolent purposes on social trust and the willingness to cooperate outside of the specific group. While it is true that people who are "joiners" also generally trust others more, this seems to be an effect of self-selection. People who-for some other reason-score high on the social ability to trust and cooperate with others join voluntary associations disproportionately. However, activity in such organizations does not add much in these desired traits, at least not for adults. Members become purely more trusting of their fellow members and they cooperate more for group purposes only (Stolle 2001, Uslaner 2002). Thus the evidence that associational membership of adults creates social capital that can be used in the wider society simply does not hold (Delhey and Newton 2003; Claiborn and Martin 2000; Herreros 2004, Kuenzi 2004, Uslaner 2002, Wollebæck and Selle 2002, Kim 2005). Other types of social interactions might do the job, yet a second problem occurs.

The second issue is that even if we accept the importance of voluntary engagement, not all associations serve a normatively desirable purpose. In fact, many associations are established to create distrust. Alan Brinkley refers to parochial communities that do not reach out but instead manifest and nurture an inward-looking and segregating culture (1996). Sheri Berman (1997) has argued that the Nazis in Weimar Germany used existing voluntary associations as vehicles for their "Machtübername”. Far from such extreme cases, some voluntary associations may use their power, for example as producer organizations, to extract resources from society in a way that comes close to blackmail, giving undue or disproportional advantages to its members to the detriment of the rest of society (Henderson 2002). 
The problem of having good and bad associations is readily admitted in social capital research, and promising new analyses distinguish groups according to the degree of contact members have with individuals unlike themselves. This distinction has been labeled as bridging (contact with many people who are dissimilar) versus bonding (contact with people like oneself) social interaction. Bridging interactions are believed to create more desirable outcomes (Putnam 2000). In a similar vein, Warren distinguishes between groups oriented toward status, group identity, and material goods, as well as those focused on inclusive social, public, or identity goods (2001). However, both theoretical accounts are still up for empirical testing (Marschall and Stolle 2004). Generally, the struggle to distinguish between 'the good, the bad and the ugly' in the world of voluntary associations underlines the lack of theoretical parameters that define a micro-theory of social capital. Our conclusion from this research is that the use of membership in adult voluntary associations as a measurement of social capital should be handled with great caution, and that its use as a producer of social capital is in all likelihood misplaced.

\section{The Institution-Centered Approach}

As a response to the society-centered approach, the institution-centered accounts of social capital theory claim that for social capital to flourish it needs to be embedded in and linked to the political context as well as formal political and legal institutions (Berman 1997; Encarnación, 2006; Hall 1999; Levi 1998; Tarrow 1996; Kumlin and Rothstein 2005). According to this group of scholars, government institutions and policies create, channel, and influence social capital. However, it is noteworthy that the "new institutionalism" and the social capital research agenda have been mostly disconnected (cf. Thelen 1999). For example, in his overview of "the new 
institutionalisms," Peters identifies no less than six different institutional approaches in political science and concludes that these six approaches and social capital research are mutually exclusive. Summarizing the many institutionalist approaches, Peters claims that "the concepts of 'social capital' and 'civil society' are really ways of saying that without the right set of social values, structural manipulation and constitution writing will produce little positive results” (1999:88). However, Peters also refers to the work on democratization by Stepan and Linz, who emphasize the importance of institution building for changing citizens' values. According to Peters:

This approach argues, although perhaps not so boldly, that if effective institutions can be constructed and managed then in time (and perhaps not very much time), the appropriate values will also be created (Peters 1999, p. 88).

We can distinguish two main types of institutional arguments in relation to social capital: an attitudinal approach and an institutional-structural approach. In the former, scholars examine the relationship between institutional/political trust and generalized trust. For example, Hall indicates that political trust and generalized trust are correlated in Britain (Hall, 1999). Kaase discusses the consistently positive but weak correlation between the two types of trust in crossnational survey samples (Kaase, 1999: 14). However, interpretations of this correlation vary. Some recognize the correlation between the two types of trust, but see generalized trust mostly as a predictor of political trust. For example, Lipset and Schneider claim that in the United States, what they call the "personal characteristic of trust in others" might explain developments in public confidence: “A general feeling of confidence in institutions seems to derive from a personal outlook of optimism, satisfaction and trust” (1983: 120ff.). Newton and Norris elaborate 
this causal flow when they find a strong positive correlation at the aggregate level in the analysis of the World Value Surveys in seventeen trilateral democracies. They interpret their findings as evidence that social capital "can help build effective social and political institutions, which can help governments perform effectively, and this in turn encourages confidence in civic institutions” (2000). This is also the logic of Putnam's argument, in which he shows that regional governmental performance depends on levels of regional social capital (1993). The problem with these analyses is that it is not clear how the causality operates. For example, using the U.S. General Social Surveys (GSS), Brehm and Rahn found that confidence in institutions has a larger effect on interpersonal trust than the other way around (Brehm and Rahn, 1997:1014ff.).

We see three main problems with the attitudinal arguments regarding the relationship between institutions and social capital. The first is that attitudes are not connected to the actual institutional characteristics. We do not know what it is in the institutional characteristics that may generate or destroy generalized trust. Secondly, since there are a variety of forms of institutional trust that we can identify in the study of advanced industrialized democracies, it is problematic to collapse them all under one label (trust in government). We argue that the reason why several studies find weak or no correlations between generalized trust and trust/confidence in political institutions is that they focus on political institutions in general without further specification. The third problem is that the mechanism for both causal claims remains unclear. Given Putnam’s (1993) logic from generalized trust to institutional performance to confidence in politicians, we do not know how trusting people create better service performance and better local politicians who are more responsive. Do more trusting citizens contact governmental officials more frequently to pressure them into good performance? Or is it that local politicians 
just reflect the culture of trust or distrust that prevails in their local societies? Our argument is that the reverse logic is just as plausible.

The second institutional approach overcomes some of these problems. This approach centers on the role of the state as a source of social capital generation (Tarrow, 1996: 395). States, for example, enable the establishment of reliable contracts between citizens in that they provide information and monitor legislation about contracts, and enforce rights and rules that sanction lawbreakers, protect minorities and actively support the integration and participation of citizens (Levi, 1998: 85ff.). Certain types of institutions, such as those that deal with lawbreakers, are also emphasized. Yet what is still missing here is a specification of how the causal mechanism between institutional arrangements and generalized trust works.

\section{3) The Role of Political Institutions-But Which Ones?}

As stated above, the problem is that many forms of institutional trust and confidence are collapsed under one label as "trust in government." Our point is that the literature has not distinguished between confidence in the institutions on the representational side of the political system (parties, parliaments, cabinets, etc.) and confidence in the institutions on the implementation side of the political system. The theoretical reason for why the confidence that people place in these two types of political institutions differ is the following. On the representational side, one of the main roles for political institutions is to be partisan. A political party that holds government power, or the majority in a Parliament, is supposed to try to implement its ideology in a partisan way. Thus, people that support the ideology of the ruling party (or parties) are likely to have confidence in them, while citizens that oppose their ideology 
are likely to report a lack of confidence. However, it is less likely that this type of partisan trust or distrust should influence one's generalized trust in other people. There is to our knowledge no plausible causal mechanism linking these two phenomena. This is why we usually find a strong correlation between political leanings and political trust but a weak correlation between confidence in these types of political institutions and social trust (for the original argument see Citrin 1974 and also Newton 1999a; Newton and Norris 2000). We believe that the weak findings of causal relationships between generalized trust and "trust in government" are mostly due to this failure to distinguish between what is the cause of trust in various kinds of political institutions.

We propose that the major source of variations in generalized trust is to be found at the other side of the state machinery, namely the legal and administrative branches of the state responsible for the implementation of public policies. We argue that these branches of government need to be distinguished from the influence of representational institutions such as the legislative and the executive for three main reasons. The first is that while the basis for trusting (or distrusting) the institutions dominated by politicians is partisanship, the reason for trusting civil servants, judges, the police, or social service institutions is for their evenhandedness, and/or impartiality (Rothstein \& Teorell 2005). Secondly, compared to other political institutions, the courts, the police and the other legal institutions of the state have a special task, namely to detect and punish people who, in game theory parlance, use opportunistic strategies (we would prefer the term treacherous). In other words, these political institutions, which we label the order institutions, are in the business of taking care of people who are better not to be trusted. Thirdly, we argue that the impartiality, efficicency and fairness of street-level political institutions are important dimensions of institutional trust and confidence that can be 
conceptually separated from conventional trust in politicians, parties, and "the government”. In the following section we expand our theory about how the implementation side of the state in general and the order institutions in particular influence generalized trust.

\section{4) Institutions, corruption and social capital - the causal mechanism}

Why would unfair, corrupt, inefficient and biased practices in the administrative machinery of the state influence people's propensity to trust others in their society? The causal link is by no means obvious since there are (at least) two possible answers to this issue. The first would be the assumption that in societies where people cannot trust the police or the judicial system, citizens would compensate by increasing their trust-based networks. In this vein, Michael Woolcook writes that "rampant corruption, frustrating bureaucratic delays, suppressed civil liberties, failure to safeguard property rights and uphold the rule of law, forces communities back on themselves, demanding that they supply privately and informally what should be delivered publicly and formally” (Woolcook 2001:16). Della Porta, a leading corruption scholar, claims that in order to make corrupt exchanges, one has to trust the others who are involved in corruption:

In all illegal systems of exchange, a high degree of trust and reciprocity is necessary among participants, so the internalization of some rules of the game is therefore necessary. A good reputation for respecting the terms of the illegal exchange, which participants often call 'honesty', is valued by the actors involved. (Della Porta 2000:223). 
However, the type of trust that can thrive in such communities would be particularized and not generalized trust. For example, the small dense niche networks in former East Germany characterized by high levels of in-group trust were so special because they actually were created as a protection against weak ties and other types of broader networks (Völker and Flap 2001). The high degree of norm conformity that Della Porta depicts among those who are involved in corruption may be plausible, but this is a specific type of trust relations, that cannot be revealed to the outside world. Moreover, people involved in corruption need not really trust one another, because they are in a situation of "mutual deterrence". By this we mean that both parties stand to lose if the corrupt exchange is revealed. Deterrence is not exactly the same as trusting that the other will not defect. Based on very interesting empirical evidence, Varese argues that the internal operations of criminal organizations such as the Mafia are not at all based on trust, but rather on fear, suspicion and deep mistrust (Varese 2004).

When it comes to attitudes of a generalized nature, such as generalized trust, our argument is that things work the other way around. A biased, unfair and corrupt administrative system generally goes hand in hand with low levels of social capital, particularly when measured as generalized trust. Our theoretical argument runs as follows: Institutions of law and order have one particularly important task, namely to detect and punish people who are "traitors", that is, those who break contracts, offer or take bribes, engage in clientelistic operations, cheat, steal and do other such non-cooperative things and who therefore should not be trusted. Thus, if citizens think that these order institutions do what they are supposed to do in a fair, reasonably efficient and unbiased manner, then they also have reason to believe that the chance of people getting away with treacherous behavior is relatively small. If so, citizens believe that most people have good reason to refrain from acting in a treacherous manner and because of this, they conclude 
that "most people can be trusted." However, we wish to emphasize that it is not just the efficiency with which treacherous behavior is punished that matters for generalized trust, but the combination of efficiency and fairness of order institutions. Police officers, social service bureaucrats, judges, and public school teachers are both representatives of the people as well as exhibitors of institutionalized values. In short, their behaviors function as important signals to citizens about the moral standard of the society in which they live (cf. Kydd 2000, Delhey \& Newton 2004).

This theory might work asymmetrically, in the sense that over time the building of fair and efficient institutions might yield slower and less visible success than the decline in institutional quality. This asymmetry is expected as generally trust is more easily destroyed than created (Offe 1999).

Our theory helps to identify some of the important dimensions of state institutions that are closely related to generalized trust. ${ }^{1}$ Below, we develop four different parts of this causal mechanism between institutional characteristics and generalized trust. Various levels of institutional efficiency and fairness:

1. influence the individual agent's perception of his/her safety and security. The absence or presence of fear of others will obviously influence the belief that "most other people" ought/ or ought not to be trusted.

2. determine the individual agent's inference from those who are given the responsibility of guarding the public interest to the rest of society. For example, if those in positions of responsibility cannot be trusted, then "most other people" can surely not be trusted.

3. shape the observance of the behavior of fellow citizens, as institutional fairness sets the tone. The message of corrupt systems is, for example, that in order to get what one needs in life, one 
must be engaged in various forms of corruption. Hence, the individual agent will witness the use of corruption amongst fellow citizens, and will feel obliged to engage in corrupt practices in order to get what he or she deems necessary in life. However, there cannot be any generalized trust in those individuals who just take advantage of others and the system.

4. cause positive or negative experiences with these institutions when in direct contact with them. Corrupt and unfair institutions, for example, might lead to experiences of discrimination and injustice, which negatively influence generalized trust.

\section{Empirical Illustrations}

\subsection{Data and Methods}

We will illustrate our theory by using a variety of data sources and methods. First, we explore in a pooled cross-sectional data set whether our general argument about varieties of institutional confidence and trust holds, and whether certain types of institutions such as the legal system, the police and social welfare institutions play a more important role for generalized trust than the political/representational institutions. The question of the sources of social capital is of course best explored in a longitudinal setting, thus in the second part, we use the longitudinal character of the World Value Survey and estimate how the changes in attitudes about institutions relate to the changes in generalized trust in various societies. In the third part, we go a step further and move beyond this attitudinal approach to include measurements of the institutions themselves. This empirical illustration of our theory requires the merging of aggregate statistical institutional measurements (taken before the survey to assure the correct causal logic) with the aggregate cross-sectional World Value Survey. Fourth, an essential contribution of our work is 
that we do not just show how the causal mechanism specified captures the way institutions might influence aggregate attitudes, but we add tests at the micro-level as well. Are individuals who have experienced corruption, unfair institutions, discrimination, or lack of protection, less trusting as well?

For the various steps we utilize a longitudinal cross-national sample provided by the World Values Survey, as well as data from several national country surveys such as Sweden and Canada. Our cross-national survey data is merged with aggregate statistical data at the country level. Our data sources include:

- The various waves of the World Values Surveys (1980/1990/1995-97)2 .

- International Country Risk Guide (ICRG) Data which provides annual values for indicators of the quality of governance, 1982-1997.

- Governance Indicators for 1996-2002 from the World Bank.

- The pooled data from the Swedish survey conducted by the SOM (Society - Opinion - Media) institute at Göteborg University, Sweden. ${ }^{3}$

- The national sample of the Equality, Security and Community (ESC) survey of Canada, which was completed at the Institute for Social Research (ISR) York University in 1999/2000. ${ }^{4}$

\subsection{Varieties of Institutional Trust-A General Exploration}

Our previous discussion demonstrated that there are at least two dimensions along which citizens might judge political institutions: they expect representatives of political, legal, and social institutions to function as their agents; at the same time, citizens focus on neutrality, fairness, and impartiality. Moreover, we argued that citizens expect more agency and more political bias from political institutions with elected offices, whereas they expect impartiality and 
a reasonable degree of efficiency from order institutions. Our claim is, of course, that the lack of impartiality of order institutions damages generalized trust; alternatively, an institution's perceived impartiality should support generalized trust. Before we turn to such causal links, we examine the distinctions that citizens draw between various institutions. Can we actually determine the difference between trust in political institutions that are perhaps seen as partisan, and trust in order institutions from which citizens should expect more fairness and impartiality?

\section{Table 1}

Confidence in Various Institutions

\begin{tabular}{|l|l|l|l|}
\hline & $\begin{array}{l}\text { Factor 1: } \\
\text { Partisan } \\
\text { Institutions }\end{array}$ & $\begin{array}{l}\text { Factor 2: } \\
\text { Neutral and } \\
\text { Order } \\
\text { Institutions }\end{array}$ & $\begin{array}{l}\text { Factor 3: } \\
\text { Power } \\
\text { Checking } \\
\text { Institutions }\end{array}$ \\
\hline Confidence in Parliament & $\mathbf{8 2 9}$ & .184 & .079 \\
\hline Confidence in Political Parties & $\mathbf{7 8 2}$ & .036 & .150 \\
\hline Confidence in Government & $\mathbf{7 4 0}$ & .267 & .088 \\
\hline Confidence in the Civil Service & $\mathbf{5 7 6}$ & .282 & .172 \\
\hline Confidence in the Army & .060 & $\mathbf{7 9 6}$ & .060 \\
\hline Confidence in the Police & 258 & $\mathbf{6 9 4}$ & .056 \\
\hline Confidence in Legal Institutions & .282 & $\mathbf{6 3 9}$ & .241 \\
\hline Confidence in the Press & 153 & .118 & $\mathbf{8 8 7}$ \\
\hline Confidence in TV & 149 & .131 & $\mathbf{8 7 8}$ \\
\hline Explained Variance (Rotation Sums of & $26 \%$ & $19 \%$ & $19 \%$ \\
\hline quared loadings) & & & \\
\hline
\end{tabular}

Results represent loadings from a factor analysis (extraction method: Principal Component Analysis) with Varimax rotation. Data Source: World Value Survey, Wave 3. Number of countries=56, Number of included respondents: $64,997$.

In order to see whether trust in various political institutions actually does fall into different dimensions, we subject the individual level third wave of the World Values Survey to a factor 
analysis. ${ }^{5}$ As the results in Table 1 indicate, citizens from 56 countries make distinctions between types of confidence in institutions according to a list of nine different types of confidence. The factor analysis (principal component, with varimax rotation) reveals that three different dimensions of institutions emerge. ${ }^{6}$ Indeed most political institutions with elected offices fall under the first dimension, such as confidence in parliaments, governments, political parties, and - to our surprise-the civil service. In many countries, it may be that the high-level civil service is seen as partisan and as an extension of elected governmental offices, and indeed in various countries high-level civil servants are often politicized (Halligan 2003). The second dimension reflects the group of order institutions that are expected to function with less political bias and in an impartial manner, even though the actual experiences in authoritarian systems, for example, are sometimes very different. Under this dimension falls trust in the army, legal institutions and the police. A third dimension taps confidence in institutions that are mostly control institutions that check the power of institutions with elected offices, and this includes the media (see Table 1). In other words, citizens do make distinctions between government institutions in the way our theory predicts, particularly as political institutions are distinguished from those that help preserve law and order.

Table 2

Trust in Institutions in Sweden

\begin{tabular}{|c|c|c|c|}
\hline & $\begin{array}{c}\text { Factor 1: } \\
\text { Partisan } \\
\text { Institutions }\end{array}$ & $\begin{array}{c}\text { Factor 2: } \\
\text { Neutral and } \\
\text { Order } \\
\text { Institutions }\end{array}$ & $\begin{array}{c}\text { Factor 3: } \\
\text { Power } \\
\text { Checking } \\
\text { Institutions }\end{array}$ \\
\hline Trust in Government & $\mathbf{. 8 7 5}$ & .158 & .047 \\
\hline Trust in Parliament & $\mathbf{. 8 7 2}$ & .206 & .100 \\
\hline Trust in the Local Government & $\mathbf{. 6 6 6}$ & .253 & .187 \\
\hline Trust in the Health System & .083 & .744 & .043 \\
\hline Trust in the Police & .209 & .727 & .042 \\
\hline Trust in the Defense System & .151 & $\mathbf{. 6 3 5}$ & .093 \\
\hline Trust in Schools & .154 & .531 & .249 \\
\hline Trust in the Legal System & .371 & .515 & .153 \\
\hline Trust in Newspapers & .127 & .101 &. $\mathbf{8 3 1}$ \\
\hline Trust in TV & .105 & .165 & $\mathbf{. 8 3 0}$ \\
\hline Explained Variance (Rotation Sums of & $22 \%$ & $22 \%$ & $15 \%$ \\
\hline squared loadings) & & & \\
\hline
\end{tabular}

Results represent loadings from a factor analysis (extraction method: Principal Component Analysis) with Varimax rotation. Data Source: SOM survey 1996-2003, Number of included respondents: 19,039. 
A cross-check with survey results from Sweden should verify our analysis. The Swedish SOM data include a variety of questions on trust in political institutions, ${ }^{7}$ ranging from institutions of the welfare state such as schools and the health system to political institutions such as parliament and the government. Using the yearly SOM surveys from 1996 to 2003 we reach a similar result: citizens in Sweden make parallel distinctions between different types of trust in institutions, according to a list of ten different types of trust. The factor analysis (principal component, with varimax rotation) reveals that three different dimensions of institutions emerge. Again, most political institutions with elected offices fall into the first dimension, which includes confidence in parliaments, governments, and local governments. The second dimension again reflects the group of institutions that are of a more permanent character and less political in nature; they include the public health system, the public school system, the police, legal institutions, and defense. Here, typical order institutions and those of the welfare state come together on one dimension as predicted by our theoretical framework. The third dimension taps trust in control institutions that check the power of institutions with elected offices, and includes the media. This result nicely confirms the findings from the WVS data. The question now is whether these different types of institutional confidence also reveal differences in their relationship to generalized trust. We will go beyond the attitudinal approach and analyze whether the institutional characteristics of fairness and impartiality versus corruption explain levels of generalized trust in the section that follows this analysis. 


\subsection{Perceptions of Institutions and Generalized Trust-the Attitudinal Approach}

Even more interesting in the light of our argument is the relationship between the dimensions of institutional confidence and generalized trust. The spread of generalized trust is very wide: it ranges from five to six percent in Peru and Brazil to over 60 percent .in Sweden and Norway. In the large cross-national sample of the WVS, the correlation between confidence in partisan institutions, as well as between confidence in power-checking institutions and generalized trust is both negative and low (see Figure 1a for evidence of the former). As predicted by our theory, there is no relationship between political institutions with elected office and generalized trust at the aggregate level. Trust in solely political institutions with elected office is mostly determined by party preference and political ideology (Citrin 1974). At the individual level, this kind of trust should fluctuate much more over time, depending on who is in power. However, in line with our expectations, we find a rather strong relationship between aggregate levels of confidence in order institutions and generalized trust. The results support the claim that societies in which the impartiality of the order institutions cannot be guaranteed, as expressed by lower citizens' confidence in these types of institutions, also show lower levels of generalized trust (and vice versa), see Figure 1b. 
Figure $1 a^{8}$

Confidence in Partisan Institutions and Generalized Trust

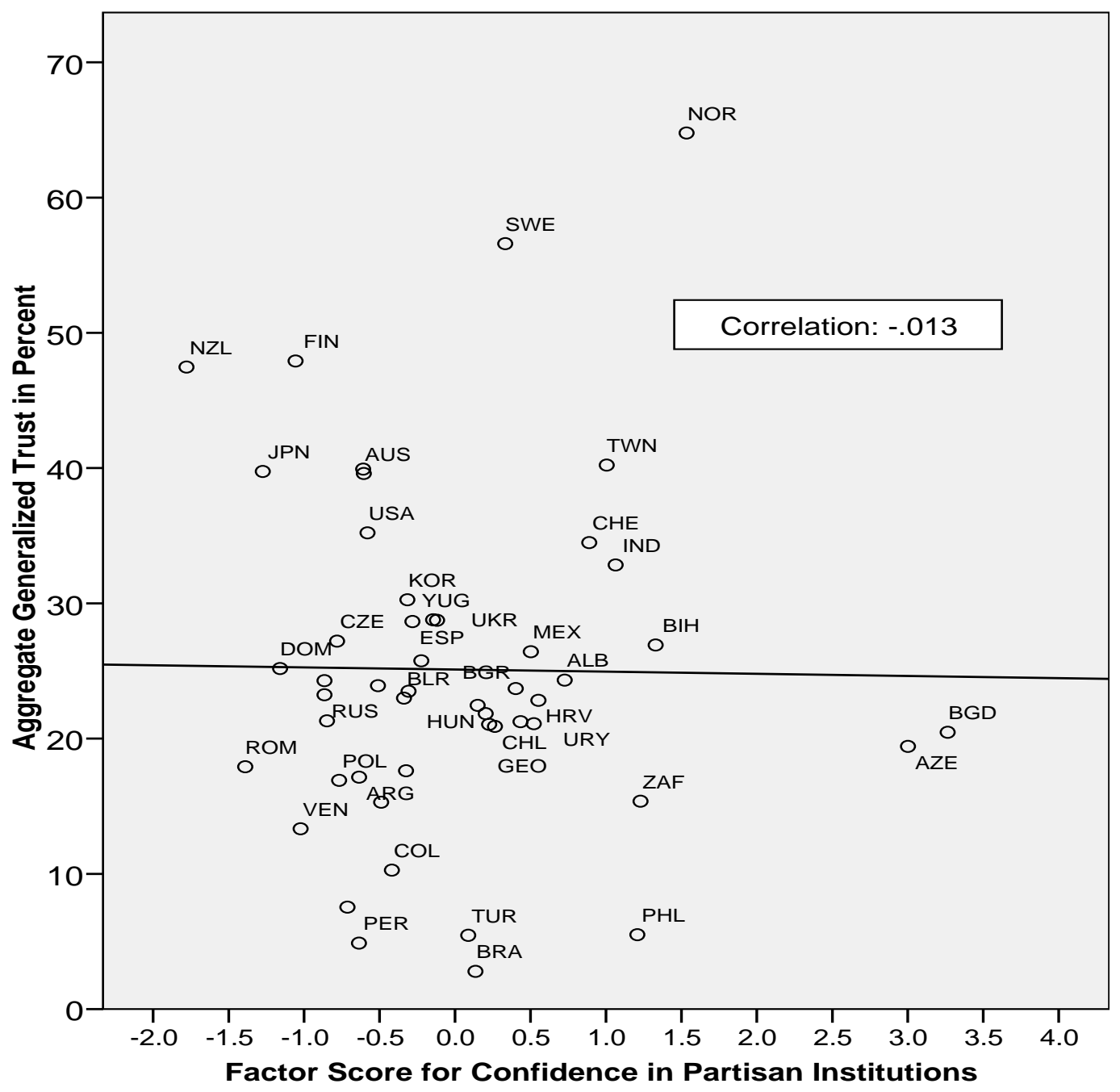


Figure $1 b^{8}$

Confidence in Order Institutions and Generalized Trust

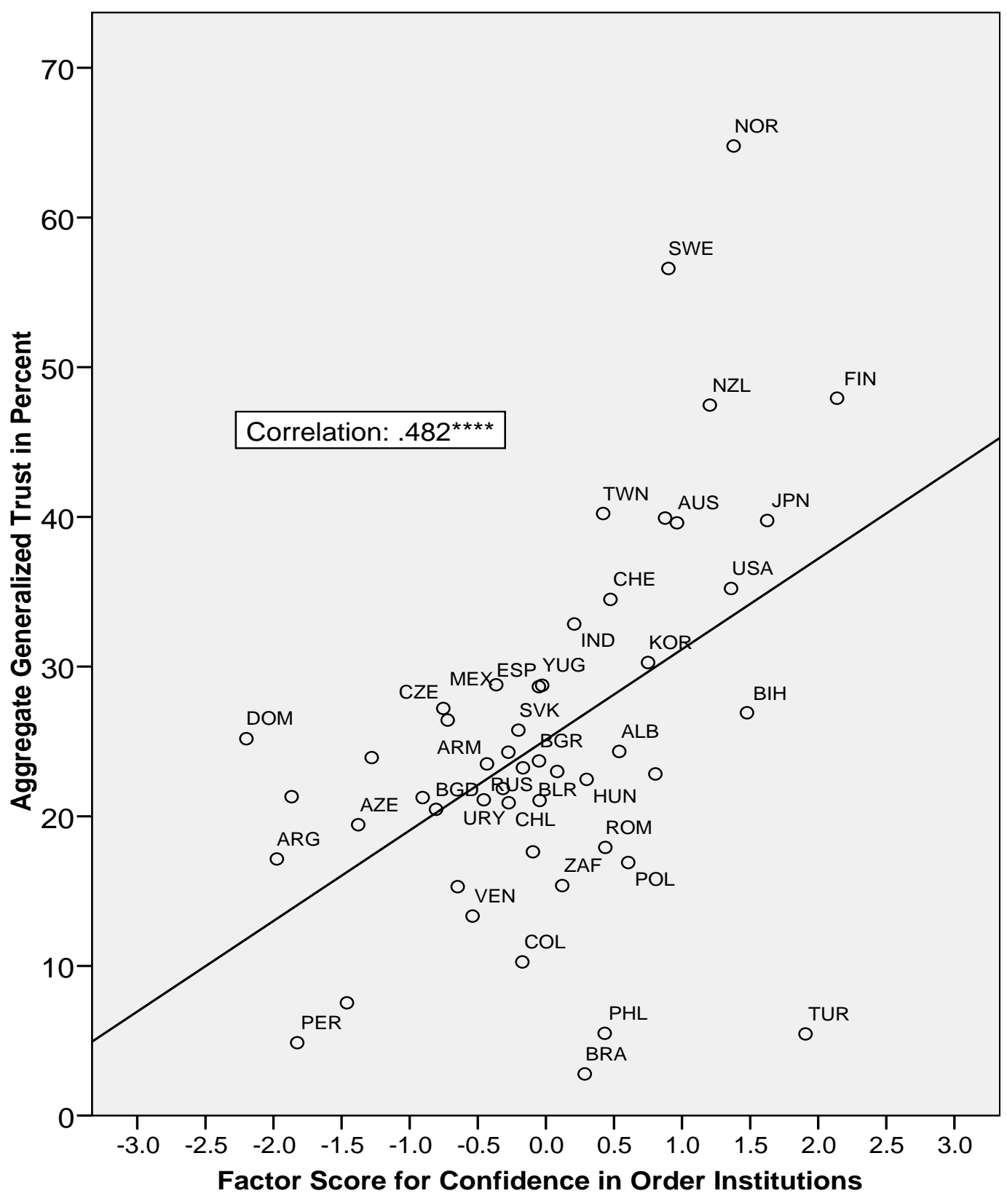


Surely the development of our causal mechanism ensures a causal logic that underlies our empirical analysis, yet if institutions are in any way responsible for social capital in the form of generalized trust, then we ought to see a connection longitudinally as well. In other words, if institutions become more or less impartial over time, we would expect a positive or negative effect on generalized trust respectively. In fact we suggested that these effects might be asymmetrical in the sense that a loss in impartiality might be more devastating to generalized trust than a gain is to its development. Accordingly, we would expect strong negative consequences for generalized trust when trust in order institutions has declined in countries over time. 
Figure2 $^{9}$

\section{Changes in Varieties of Trust}

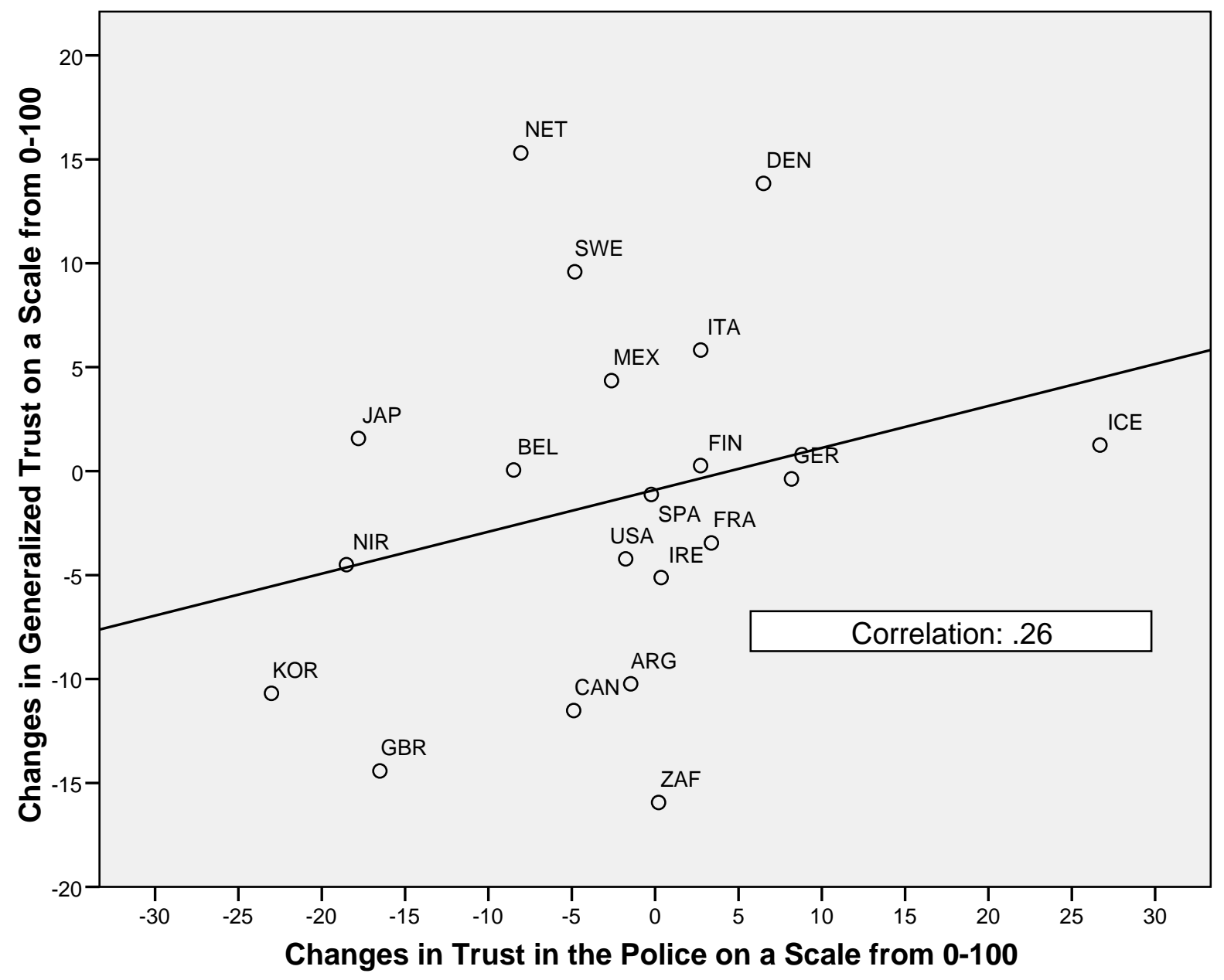


For Figure 2, we compiled data from countries that participated in the first and last waves of the World Value survey. Since the first wave was taken in 1981 and the last one more recently in the year 2000, we believe that this 19 year period represents a good time frame for examining the relationship between longitudinal changes in institutional trust and generalized trust. More precisely, we will analyze whether changes in trust in the police are related to generalized trust. ${ }^{10}$ Unfortunately, only 20 countries have data in both waves; very few countries experienced a slip in police trust, most visibly Britain, Northern Ireland, South Korea, and Japan. Two of these countries, Britain and South Korea, also experienced a rather strong decline in generalized trust. Overall, the changes in police trust and changes in generalized trust over this period of about 20 years are somewhat related. Generally, countries with a loss of 10 percentage points in confidence in the police in this period had on average a 6 percentage point loss in generalized trust. A positive or stable trend did not lead to significant positive changes in generalized trust. This result suggests that negative institutional trends relate to generalized trust, whereas it is not certain whether positive trends have an equally positive relationship. The overall correlation of changes in police trust and changes in generalized trust is .26 for the small sample of 20 countries (the relationship is not significant).

Since we have established that citizens distinguish between various types of institutional trust, and that at the aggregate level generalized trust is more closely related to trust in order institutions as compared to institutions with elected offices, our next task is to analyze which institutional experiences relate to generalized trust. Our theory about the causal mechanism 
entails that important aspects of confidence in order institutions are institutional efficiency, in terms of protection and safety, as well as institutional impartiality and fairness. Particularly, we emphasized four causal linkages from institutional experiences to generalized trust, namely citizens' feelings of safety and protection, citizens' inferences from elites' and fellow citizens' behavior, as well as their experiences with discrimination. If these are correct, we should see that citizens are less able to trust when they experience widespread corruption, inefficient institutions, unreliable police, as well as arbitrariness and bias of courts. We will analyze some of these propositions at the macro and micro-levels below.

\subsection{Institutional Characteristics and Generalized Trust-Macro Results}

The question, then, is whether not only perceptions of order institutions but also actual "objective" variances in their characteristics are related to the spread of generalized trust across countries. For this part of our analysis, we utilize the aggregate data of the World Value survey, for which we collapse the second and third wave into a cross-sectional data set. For the multivariate analysis, we identify two important institutional dimensions, which according to our theory should matter most for social capital: institutional effectiveness and institutional impartiality. We have chosen the "Government Effectiveness" point estimate indicator for 1996 used by the World Bank’s research unit (Kaufmann, Kraay, Mastruzzi 2003) as our measure of institutional effectiveness. It measures the competence of civil servants, the independence of the civil service from political pressures, and the credibility of the government's commitment to policies. The main focus of this index is on "inputs" required for the government to be able to produce and implement good policies and deliver public goods. The impartiality measure is complementary and delves into the level of bias in important institutions. It is a summated rating index of three measures from the IRIS ${ }^{11}$ data that taps the impartiality of courts and the 
bureaucracy as well as the corruption in politics more generally (Knack and Keefer 1998); the three items scale with a Cronbach's alpha of $.927 .{ }^{12}$ In addition to our measures of institutional efficiency and impartiality we also include the common measure of longevity of democracy (Inglehart 1999) as a measure of overall institutional quality over time. Longterm democratic institutions should imply impartial rule of law and fair police practices compared to authoritarian regimes, although there is of course a strong variance between democracies as to the level of impartiality of their institutions. Furthermore, we include a measure of equality of outcomes, the GINI index. More egalitarian societies without major societal socio-economic gaps are believed to achieve higher levels of generalized trust than societies in which inequality is rampant (Rothstein and Uslaner 2005).

In our multivariate model, we also include control variables that are related to generalized trust at the country level. Basic patterns of religion (Inglehart 1999), ethnic and religious fractionalization (Alesina and La Ferrara 2000), the experience of communism (Howard 2003), as well as classic network indicators of social capital such as aggregated memberships in voluntary associations (Putnam 1993) should all matter for generalized trust. For example, Protestant countries, countries with a high GDP per capita and high educational secondary enrollment rates, as well as those with fewer ethnic and religious divisions should be better able to develop interpersonal citizen trust than other countries. Of course, the GDP per capita (Inglehart 1999) and educational enrollment (Brehm and Rahn 1997) also play a role, yet we do not include those factors in the baseline model as they are highly correlated with our institutional variables and other controls. We should see that institutional impartiality and effectiveness matter for generalized trust holding other factors that explain variances in trust constant. 
Table 3: Relationships with Generalized Trust Aggregate Level Correlation Table

\begin{tabular}{|lcc|}
\hline Variables & Correlation & N \\
Socio-political Control Variables & & \\
\hline Protestant Countries versus others religions (Dummy & $0.5473^{* * * *}$ & 71 \\
var.) & $-0.3670^{* * *}$ & 71 \\
Ethnic Fractionalization & 0.0333 & 71 \\
Religious Fractionalization & $-0.3257^{* * *}$ & 71 \\
Former Communist Country & 0.1090 & 71 \\
Associational Membership Scale & & \\
Socio-economic Variables & & 68 \\
\hline Gross Domestic Product & $0.5964^{* * * *}$ & 68 \\
Secondary School Enrollment & $0.4730^{* * * *}$ & \\
\hline Institutional Variables & & 71 \\
\hline Length of Democracy & & 69 \\
Gini Coefficient & $0.6591^{* * * *}$ & 68 \\
Institutional Efficiency & $-0.3646^{* * *}$ & 53 \\
\hline Institutional Impartiality & $0.6455^{* * * *}$ & \\
\hline
\end{tabular}

Note: Entries are correlation coefficients between the indicated variable and aggregate generalized trust. ${ }^{*}=\mathrm{p}<.1 ; * *=\mathrm{p}<.05$; $* * *=\mathrm{p}<.01 ; * * * * 0.001$. Data Source: includes countries from the second and third wave of the World Value Survey.

In Table 3 we present at first bivariate results of our main indicators and generalized trust. The table reveals that most variables perform according to the expectations. Non-protestant countries, and those with high levels of ethnic fractionalization (not so much religious fractionalization), former communist countries, and those with low GDP per capita and low school enrolments all have lower levels of generalized trust. Institutions matter as well: 
institutional efficiency, impartiality, equality of outcomes measured by low GINI scores, as well as democratic longevity are all positively linked with aggregate trust.

Table 4: Institutional Characteristics and Generalized Trust

\begin{tabular}{|c|c|c|c|c|c|c|c|c|c|}
\hline $\begin{array}{l}\text { Independents } \\
\text { Variables }\end{array}$ & $\begin{array}{l}\text { Baseline } \\
\text { Model }\end{array}$ & Model 2 & Model 3 & Model 4 & Model 5 & Model 6 & Model 7 & Model 8 & Model 9 \\
\hline Protestant Dummy & $\begin{array}{c}.1568^{* * *} \\
(.0476)\end{array}$ & $\begin{array}{l}.0782 * \\
(.0419) \\
\end{array}$ & $\begin{array}{c}.1642^{* * * * *} \\
(.0451)\end{array}$ & $\begin{array}{c}.1777^{* * * *} \\
(.0424)\end{array}$ & $\begin{array}{c}.1278^{* * * *} \\
(.0446)\end{array}$ & $\begin{array}{c}.1497^{* * * * *} \\
(.0442)\end{array}$ & $\begin{array}{l}.1105^{* *} \\
(.0433)\end{array}$ & $\begin{array}{l}.0946 * * \\
(.0440)\end{array}$ & $\begin{array}{l}.0877 * \\
(.0437) \\
\end{array}$ \\
\hline $\begin{array}{l}\text { Ethnic } \\
\text { Fractionalization }\end{array}$ & $\begin{array}{c}.1695 * * \\
(.0844) \\
\end{array}$ & $\begin{array}{l}-.1234 \\
(.0768)\end{array}$ & $\begin{array}{l}-.1157 \\
(.1002)\end{array}$ & $\begin{array}{l}-.1157 \\
(.1032) \\
\end{array}$ & $\begin{array}{l}-.1012 \\
(.1027) \\
\end{array}$ & $\begin{array}{l}-.0808 \\
(.0822)\end{array}$ & $\begin{array}{l}-.0991 \\
(.1001)\end{array}$ & $\begin{array}{l}-.0878 \\
(.0903)\end{array}$ & $\begin{array}{l}-.0773 \\
(.0868)\end{array}$ \\
\hline $\begin{array}{l}\text { Religious } \\
\text { Fractionalization }\end{array}$ & $\begin{array}{l}.1078 \\
(.0851)\end{array}$ & $\begin{array}{c}.0945 \\
(.0784)\end{array}$ & $\begin{array}{c}.0747 \\
(.0909)\end{array}$ & $\begin{array}{l}.0850 \\
(.0893)\end{array}$ & $\begin{array}{c}.0842 \\
(.0861)\end{array}$ & $\begin{array}{c}.0634 \\
(.0801) \\
\end{array}$ & $\begin{array}{c}.0141 \\
(.0914)\end{array}$ & $\begin{array}{c}.0094 \\
(.0867)\end{array}$ & $\begin{array}{l}.0199 \\
(.0835)\end{array}$ \\
\hline Communist & $\begin{array}{c}-.0775 * * \\
(.0357)\end{array}$ & $\begin{array}{c}.0269 \\
(.0375)\end{array}$ & $\begin{array}{l}-.0140 \\
(.0354)\end{array}$ & $\begin{array}{l}-.0496 \\
(.0368)\end{array}$ & $\begin{array}{c}-.0974 * * \\
(.0424)\end{array}$ & $\begin{array}{l}.0049 \\
(.0393)\end{array}$ & $\begin{array}{l}-.0481 \\
(.0468)\end{array}$ & $\begin{array}{l}.0287 \\
(.0733)\end{array}$ & $\begin{array}{l}.0406 \\
(.0732)\end{array}$ \\
\hline $\begin{array}{l}\text { Associational } \\
\text { Membership }\end{array}$ & $\begin{array}{l}-.2045 \\
(.3434) \\
\end{array}$ & $\begin{array}{l}-.2653 \\
(.3299) \\
\end{array}$ & $\begin{array}{l}-1873 \\
(.3568)\end{array}$ & $\begin{array}{l}-.1078 \\
(.3317)\end{array}$ & $\begin{array}{l}-.0386 \\
(.3212)\end{array}$ & $\begin{array}{l}-.1284 \\
(.3403)\end{array}$ & $\begin{array}{l}-.1624 \\
(.3499)\end{array}$ & $\begin{array}{l}-.2012 \\
(.3365)\end{array}$ & $\begin{array}{l}-.2246 \\
(.3128)\end{array}$ \\
\hline $\begin{array}{l}\text { Length of } \\
\text { Democracy }\end{array}$ & & $\begin{array}{c}.0036 * * * * \\
(.0008)\end{array}$ & & & & & & & \\
\hline $\begin{array}{l}\text { Gross Domestic } \\
\text { Product }\end{array}$ & & & $\begin{array}{l}.0052 * \\
(.0031)\end{array}$ & & & & & & \\
\hline $\begin{array}{l}\text { Sec. School } \\
\text { Enrollment } \\
\end{array}$ & & & & $\begin{array}{l}.0014^{*} \\
(.0007)\end{array}$ & & & & & \\
\hline Gini Index & & & & & $\begin{array}{c}-.0044^{* *} \\
(.0021)\end{array}$ & & & & \\
\hline $\begin{array}{l}\text { Institutional } \\
\text { Effectiveness }\end{array}$ & & & & & & $\begin{array}{c}.0671^{* * * * *} \\
(.0192) \\
\end{array}$ & & $\begin{array}{l}.0757 \\
(.0493) \\
\end{array}$ & $\begin{array}{c}.0791 \\
(.0501) \\
\end{array}$ \\
\hline $\begin{array}{l}\text { Institutional } \\
\text { Impartiality Index }\end{array}$ & & & & & & & $\begin{array}{c}.0683 * * * \\
(.0222)\end{array}$ & $\begin{array}{l}.0088 \\
(.0485) \\
\end{array}$ & $\begin{array}{l}-.0502 \\
(.0620)\end{array}$ \\
\hline $\begin{array}{l}\text { Interaction } \\
\text { Institutional Impart. } \\
\text { Index*Institutional } \\
\text { Effectiveness }\end{array}$ & & & & & & & & $\begin{array}{l}.0519 * * \\
(.0221)\end{array}$ & \\
\hline $\begin{array}{l}\text { Interaction highly } \\
\text { efficient institutions } \\
\text { with impartiality }{ }^{a}\end{array}$ & & & & & & & & & $\begin{array}{l}.1455 * * * \\
(.0520)\end{array}$ \\
\hline Constant & $\begin{array}{c}.3338 * * * * \\
(.0401)\end{array}$ & $\begin{array}{c}.2193 * * * * \\
(.0351)\end{array}$ & $\begin{array}{c}.2520^{* * * * *} \\
(.0524)\end{array}$ & $\begin{array}{c}.1950 * * * \\
(.0674)\end{array}$ & $\begin{array}{c}.4822 * * * * \\
(.0854)\end{array}$ & $\begin{array}{c}.2639 * * * * \\
(.0418)\end{array}$ & $\begin{array}{c}.3584^{* * * * *} \\
(.0416)\end{array}$ & $\begin{array}{c}.2607 * * * \\
* \\
(.0724) \\
\end{array}$ & $\begin{array}{c}.2381^{* * *} \\
(.0747)\end{array}$ \\
\hline $\mathrm{N}$ & & & & & 69 & & 53 & 52 & 52 \\
\hline $\mathrm{R}^{2}$ & 0.3962 & .5430 & .4890 & 0.4982 & 0.4502 & 0.5239 & 0.5070 & 0.5786 & 0.6009 \\
\hline Mean VIF & 1.32 & 1.71 & 1.67 & 1.39 & 1.44 & 1.71 & 1.48 & 3.10 & 3.63 \\
\hline
\end{tabular}

Note: Entries are OLS regression coefficients with robust standard errors in parentheses. Data Source: The aggregate data of the second and third waves of the World Values Survey.

$*=\mathrm{p}<.1 ; * *=\mathrm{p}<.05 ; * * *=\mathrm{p}<.01 ; * * * * 0.001$.

${ }^{\text {a }}$ Non-efficient institutions are coded zero 
In our multivariate model, we use the Protestant culture, ethnic and religious diversity, the influence of a communist background, as well as membership in voluntary associations as the most important cultural control variables, yet we do not utilize the other factors in the baseline model, as all institutional variables are related to the longevity of democracy, GDP per capita, educational enrolment, and these variables are also related to each other. Because of multicollinearity therefore, the institutional variables are examined individually in addition to the baseline model. $^{13}$ GDP per capita and secondary school enrolment did not withstand the multivariate test and lost statistical significance in a multivariate model. As Table 4 indicates, all institutional variables are significantly related to generalized trust, even when controlling for important societal characteristics and historical experiences. Countries with high levels of generalized trust also have the most effective and impartial institutions, and the longest experiences with democracy, as well as most egalitarian socio-economic outcomes, controlled for important societal attributes.

Moreover, our theory implies that when institutional effectiveness and impartiality come together, we should see particularly strong effects on trust. We therefore created an interaction term by multiplying institutional efficiency and impartiality. Countries with institutions that are both efficient and impartial, have significantly higher levels of trust than other countries. The interaction effect accounts for $3.2 \%$ of the variance in generalized trust. ${ }^{14}$ In a second interaction model we compared countries with highly efficient institutions to all others and multiplied this score with the impartiality measure. Both models indicate that the effect of high institutional impartiality conditional upon high effectiveness is particularly strong. In order to fully examine 
the relationship between institutional characteristics and experiences as well as generalized trust, we need to analyze this connection in a multivariate micro model as well.

\subsection{Linkages at the Micro Level}

Do individual experiences with institutions also translate into specific patterns of generalized trust, as our theory would predict? To get closer to the way our causal mechanism operates at the micro level, we analyze whether trust in order institutions influences generalized trust in a multivariate setting. If trust in order institutions remains an important factor in relation to generalized trust, even when controlling for other variables, we would be yet another step closer to assembling the evidence for how the theory works at the micro level. We present results

for tests in three different data sets: the Swedish SOM surveys, the ESC Canadian national survey as well as in the second and third waves of the World Value surveys. ${ }^{15}$ 
Table 5: Explaining Generalized Trust-Individual level models

\begin{tabular}{|c|c|c|c|}
\hline & Model $1^{\mathrm{a}}$ & Model $2^{b}$ & Model 3 ${ }^{\mathrm{C}}$ \\
\hline & $\begin{array}{l}\text { SOM, Sweden } \\
(1996-2000)\end{array}$ & $\begin{array}{l}\text { ESC, Canada } \\
(2002)\end{array}$ & $\begin{array}{l}\text { WVS, } 74 \text { countries } \\
(1990 / 95)\end{array}$ \\
\hline Constant & $\begin{array}{l}5.16^{* * * * *} \\
(.12)\end{array}$ & $\begin{array}{l}-2.58 * * * * \\
(.27)\end{array}$ & $\begin{array}{l}-1.63^{* * * * *} \\
(.06)\end{array}$ \\
\hline Education & $\begin{array}{l}.10^{* * * *} \\
(.01)\end{array}$ & $\begin{array}{l}.12^{* * * * *} \\
1.13 \\
(.02) \\
\end{array}$ & $\begin{array}{l}.01^{* * * * *} \\
1.00 \\
(.00)\end{array}$ \\
\hline Age & $\begin{array}{l}.10 * * * * \\
(.01)\end{array}$ & $\begin{array}{l}.01^{* * *} \\
1.01 \\
(.00)\end{array}$ & $\begin{array}{l}.00 * * * * \\
1.00 \\
(.00)\end{array}$ \\
\hline Married & $\begin{array}{l}.10^{* *} \\
(.04)\end{array}$ & $\begin{array}{l}.17^{* *} \\
1.13 \\
(.09) \\
\end{array}$ & $\begin{array}{l}-.00 \\
.99 \\
(.03) \\
\end{array}$ \\
\hline Unemployed & $\begin{array}{l}-.28^{* * *} \\
(.09)\end{array}$ & $\begin{array}{l}-.27 * \\
.76 \\
(.15) \\
\end{array}$ & $\begin{array}{l}-.23 * * * * \\
.79 \\
(.02) \\
\end{array}$ \\
\hline Quebec (francophone) & & $\begin{array}{l}-1.16^{* * * *} \\
.314 \\
(.12) \\
\end{array}$ & \\
\hline Size of Location ${ }^{\mathrm{d}}$ & $\begin{array}{l}-.00 \\
(.00)\end{array}$ & $\begin{array}{l}-.22 * * * \\
1.24 \\
(.06)\end{array}$ & $\begin{array}{l}-.03 \\
.97 \\
(.02)\end{array}$ \\
\hline Life Satisfaction & $\begin{array}{l}.53 * * * * \\
(.03)\end{array}$ & & $\begin{array}{l}.43^{* * * * *} \\
1.54 \\
(.01) \\
\end{array}$ \\
\hline Associational Involvement & $\begin{array}{l}.84 * * * * \\
(.11)\end{array}$ & $\begin{array}{l}.30 * * * \\
1.36 \\
(.09) \\
\end{array}$ & $\begin{array}{l}.95 * * * * \\
2.58 \\
(.06) \\
\end{array}$ \\
\hline Institutional Trust in Order Institutions & $\begin{array}{l}.40^{* * * *} \\
(.03)\end{array}$ & & $\begin{array}{l}.39 * * * * \\
1.48 \\
(.04)\end{array}$ \\
\hline Rating of Courts & & $\begin{array}{l}.01 * * * * \\
1.01 \\
(.00) \\
\end{array}$ & \\
\hline Rating of Police & & $\begin{array}{l}.00^{* *} \\
1.00 \\
(.00)\end{array}$ & \\
\hline $\begin{array}{l}\text { Political trust in Political Institutions or Rating } \\
\text { of Government }\end{array}$ & $\begin{array}{l}.22 * * * * \\
(.02)\end{array}$ & $\begin{array}{l}.00 * * \\
1.00 \\
(.00) \\
\end{array}$ & $\begin{array}{l}.69 * * * * \\
1.99 \\
(.03) \\
\end{array}$ \\
\hline $\begin{array}{l}\text { Adjusted R square } \\
\text {-2 Log likelihood } \\
\text { Nagelkerke R square }\end{array}$ & .11 & $\begin{array}{l}3117.494 \\
.142\end{array}$ & \\
\hline $\mathrm{N}$ & 11,903 & 2,456 & 84,006 \\
\hline Number of aggregate units & & & 74 \\
\hline
\end{tabular}

${ }^{a}$ Model 1 uses OLS regression, as the dependent variable is an 11 point scale. Results show OLS regression coefficients with standard errors in parentheses.

${ }^{\mathrm{b}}$ Model 2 uses Logit, as the dependent variable is dichotomous. Results show logit coefficients, with odds ratios and standard errors in parentheses below.

C Model 3 uses Stata's Svylogit, as individuals are clustered in countries. Results show svylogit coefficients, with odds ratios and standard errors in parentheses below.

${ }^{d}$ Size of location is measured slightly differently in the three data sets. In the Swedish survey, villages, small towns, large towns and cities are distinguished on a four-point scale. In the Canadian survey small towns and rural areas were distinguished from census agglomeration and census metropolitan areas. In the WVS, size of location is an 8-point scale (standardized between 0-1), distinguishing the following population sizes: <2000, 2-5000, 5-10k, 10-20k, 20-50k, 50-100k, 100-500k, 500k+. 
Table 5 shows three similar models in three different data sets in which we analyze the micro-relationship between institutional experiences and generalized trust. As in our macro models, here too we include various other micro level predictors that have been shown to be important for generalized trust, such as socio-economic resources, attitudes such as life satisfaction, and, of course, trust in order institutions. Variables that have been put forth by other theoretical approaches are also included, such as associational membership and trust in political institutions (or trust in government). Many socio-economic resources emerge as important factors for trust; education is predominant but individual associational membership and attitudes such as life satisfaction are also significant. Model 1 includes trust in order institutions whichwhen controlling for all these other variables-emerges as a very strong factor: a one unit increase in trust in order institutions (a 4 point scale) corresponds to a .4 increase in generalized trust on an 11-point scale. ${ }^{16}$ The fact that trust in order institutions holds in a model in which trust in political institutions and associational membership is controlled strengthens the idea that order institutions are not unimportant for generalized trust.

In the Canadian data, we do not have the same indicators of trust in order institutions, however a ranking of some political institutions exists. According to our theory, we should find that the ranking of courts and the police as political institutions from which citizens expect impartiality and effectiveness should be highly correlated with values of generalized trust. We do indeed find the relationship between selected institutional ratings and generalized trust. Those citizens who rate courts highly are also those who trust other citizens, controlling for a variety of factors including a ranking of the government. More specifically, each additional point on the 0100 court rating scale increases the odds of generalized trust by about $10 \%$, controlling for other 
variables in the model. The courts take a more important role here than the police and the government, although these are also positively related to trust. ${ }^{17}$ Second, we also find that Quebeckers are generally less trusting than other Canadians (Soroka et al 2006). It is common for minority social and ethnic groups to experience collective discrimination from a variety of political institutions, which translates into perceived unfairness or bias, and as we argue, the lack of perceived impartiality may translate into lasting feelings of distrust towards the wider society. African-Americans in the United States, immigrants in various democratic systems as well as ethnic minorities do not perceive that the system works for them (Alesina and La Ferrara 2000; Orlando 2000). Soroka et al found that immigrants in Canada do not have a favorable view of the police (2006). Overall, holding other variables constant, generalized trust is positively related to education, age, employment, and associational membership, whereas people in larger metropolitan areas are less trusting in Canada, holding other variables constant. Most importantly, institutional evaluations of the courts shape how citizens view other people.

Finally, this individual-level relationship is confirmed in the World Value survey as well. We are using here a summated rating scale of trust in order institutions including trust in the police, trust in legal institutions as well as trust in the army. ${ }^{18}$ Stata's svylogit is utilized here in order to control for the nested structure of the cross-national data set. Controlling for socioeconomic resources, associational membership, life satisfaction, size of the community, we again find that trust in order institutions significantly relates to generalized trust. With regard to the comparison to trust in political institutions though, the results are perhaps least convincing in the World Values survey: moving from no trust to trust on the scale for order institutions yields an increase of the odds of generalized trust by about $48 \%$, controlling for other variables in the model; whereas the same unit increase on the political trust scale increases the odds of 
generalized trust by $99 \%$. Nevertheless, the importance of trust in order institutions for generalized trust holds up vis-à-vis other control variables.

\section{Conclusion}

Our argument is that the structure and characteristics of contemporary government institutions are both important and often overlooked factors that matter for the generation of generalized trust. The theory we have presented gives an explanation for how the causal flow from impartial institutions to generalized trust might operate. The procedural fairness of these institutions influences citizens’ institutional trust and, more specifically, (1) how they experience feelings of safety and protection; (2) how citizens make inferences from the system and public officials to other citizens, (3) how citizens observe the behavior of fellow citizens, and (4) how they experience discrimination against themselves or those close to them.

In our empirical section we have found support that these causal mechanisms are at work. What is special about our empirical analysis is that it works both at the micro and the macro levels. Citizens seem to make distinctions between various types of institutions, and trust in order institutions and in other institutions that implement policy is more important for generalized trust than other types of institutional confidence, in most of our models. A key point of our discussion is the direction of causality. How do we know that institutions actually shape social capital and not the other way around? Clearly, many more tests and analyses have to be preformed in order to ensure that this direction of causality holds. For example, an ideal test would be to use longitudinal data of institutional characteristics over longer periods of time that are not available at the moment. Furthermore, quasi-experimental case studies of institutional reform with pre/ and post- measurements of social capital would be an additional tool to use in establishing the causal 
flow in the creation of social capital. However, the first step in this discussion must surely be the development of a causal mechanism based on a strong theoretical account. Our empirical analyses can only be first illustrations of these theoretical insights. Taken alone, each of our results are not enough to make our point. Yet the causal mechanism we have developed and the multiplicity of results we presented throughout this article reveal a great deal about how civic attitudes such as trust are related to and most likely embedded in impartial, fair, and efficient institutions.

Finally, we believe that important policy implications may follow from our results. If the society-centered model is correct, governments can claim that the main problems that plague their societies are caused by too little volunteering. To make democracy work and the economy grow, citizens have to "get involved". However, if our theory is correct, governments cannot put the blame on their citizens for the lack of social capital. Instead, the policy message becomes a very different one, namely that the lack of social capital is caused by dysfunctional government institutions. 


\section{References}

Alesina, Alberto and Eliana La Ferrara. 2000. “The Determinants of Trust,” NBER working paper series. Nr. 7621. Berman, Sheri. 1997. Civil Society and the Collapse of the Weimar Republic. World Politics 49 (3):401429.

Brehm, J. and Rahn, W. (1997). Individual Level Evidence for the Causes and Consequences of Social Capital. American Journal of Political Science 41, 999-1023.

Brinkley, Alan. 1996. "Liberty, Community, and the National Idea," The American Prospect vol. 7 no. 29.

Citrin, Jack 1974. "The Political Relevance of Trust in Government,: in American Political Science Review vol 68, pages 973-988.

Claiborn, M.P., and P. S. Martin. 2000. Trusting and joining? An empirical test of the reciprocal nature of social capital. Political Behavior 22 (4):267-291.

Coleman, James S. 1990. Foundations of Social Theory. Cambridge, Massaschusetts: The Belknap Press of Harvard University Press.

Delhey, Jan, and Kenneth Newton. 2003. "Who trusts? The origins of social trust in seven societies." European Societies 5:93-137.

Delhey, Jan, Kenneth Newton. 2004. "Social Trust. Global Pattern or Nordic Expectionalism?”, Discussion paper 2004.202, Wissenschaftszentrum Berling für Sozialforschung..

Della Porta, Donatella. 2000. Social Capital, Beliefs in Government, and Political Corruption. In Disaffected Democracies, edited by S. J. Pharr and R. D. Putnam. Princeton: Princeton University Press.

Encarnación, Omar G. 2006. Civil Society Reconsidered. Comparative Politics 38 (3):357- 376.

Freitag, M. 2006. 'Bowling the State Back In: Political Institutions and the Creation of Social Capital.'

European Journal of Political Research, (in print).

Fukuyama, Francis. 1999. Social Capital and Civil Society. Paper read at Conference on Second Generation Reform, Nov. 8-9, 1999, at Washington.

Granovetter, Mark. 1973. “The Strength of Weak Ties.” American Journal of Sociology 78: 1360-80.

Hall, Peter. 1999. Social Capital in Britain. British Journal of Political Science 29 (3):417-464.

Halligan, John. 2003. Leadership and the Senior Service from a Comparative Perspective. In. Handbook of Public Administration, edited by B. G. Peters and J Pierre (pp. 98-108). London: Sage Publications.

Helliwell, John F. 2002. "How's Life? Combining Individual and National Variables to Explain Subjective WellBeing." Cambridge, Mass.: NBER (National Bureau for Economic Research).

Henderson, Sarah L. 2002. Selling Civil Society: Western Aid and the Nongovernmental Organization Sector in Russia. Comparative Political Studies 35 (2):139-169.

Herreros, Francisco. 2004. The Problem of Forming Social Capital: Why Trust? New York: Palgrave/Macmillan.

Howard, Marc. 2003. The Weakness of Civil Society in Post-Communist Europe.

Cambridge: Cambridge University Press.

Inglehart, Ronald. 1999. Trust, well-being and democracy. In Democracy \& Trust, edited by M. E. Warren. New York: Cambridge University Press, pp. 88-120.

Jaccard, J. (2003). Interaction Effects in Multiple Regressions. Thousand Oaks: Sage Publications.

Kaase, Max. 1999. "Interpersonal Trust, Political Trust and Non-institutionalised Political Participation in Western Europe, “ In West European Politics 22 (3).

Kaufmann, Daniel, Kraay, Aart and Mastruzzi, Massimo, "Governance Matters III: Governance Indicators for 19962002" (June 30, 2003). World Bank Policy Research Working Paper No. 3106.

Kim, Ji-Young. 2005. "'Bowling Together" isn't a Cure-All. The Relationship between Social Capital and Political Trust in South Korea." International Political Science Review 26:193-213.

Knack, Steve, and Philip Keefer. 1997. Does Social Capital Have an Economic Payoff? A Cross-Country Investigation. The Quarterly Journal of Economics 112 (4):1251-1288.

Knack, Steve and Philip Keefer. 1998. IRIS-3: International Country Risk Guide (ICRG). Data. 3rd Edition. College Park, Maryland: IRIS, East Syracuse, New York: The PRS Group, Inc.

Krishna, Anirudh. 2002. Active social capital tracing the roots of development and democracy. New York: Columbia University Press.

Kuenzi, Michelle. 2004. "Social Capital, Political Trust, and Ethnicity in West Africa." Paper presented at the Annaul Meeting of the American Political Science Association, Chicago Sept. 1-4, 2004.

Kumlin, Staffan, and Bo Rothstein. 2005. "Making and Breaking Social Capital. The Impact of Welfare State Institutions." Comparative Political Studies 38 (4): 339-365.. 
Kydd, Andrew. 2000. Overcoming Mistrust. Rationality and Society 12 (4):397-424.

Levi, Margaret. 1998. A State of Trust. In Trust \& Governance, edited by V. Braithwaite and M. Levi. New York:

Russell Sage Foundation.

Lipset, S. M. and Schneider, W. (1983). The Confidence Gap. New York: The Free Press.

Marschall, Melisssa and Dietlind Stolle (2004). "Race and the City: Neighborhood Context and the Development of Generalized Trust," in Political Behavior 26(2), 126-153.

Newton, Kenneth. 1999a. Social and Political Trust in Established Democracies. In Critical citizens : global support for democratic government, edited by P. Norris. New York: Oxford University Press.

Newton, Kenneth. 1999b. Social Capital and democracy in Modern Europe. In Social Capital and European Democracy, edited by J. W. van Deth, M. Maraffi, K. Newton and P. F. Whiteley. London: Routledge.

Newton, Ken, and Pippa Norris. 2000. Confidence in Public Institutions. In Disaffected Democracies. What's Troubling the Trilateral Countries, edited by S. J. Pharr and R. D. Putnam. Princeton: Princeton University Press.

Offe, Claus. 1999. “How can we trust our fellow citizens?” In Democracy \& Trust, edited by M. E.

Warren. Cambridge: Cambridge University Press.

Ostrom, Elinor.1990, Governing the Commons: The Evolution of Institutions for Collective Action. New York: Cambridge University Press.

Patterson, Orlando. 1999. Liberty against the democratic state: on historical and contemporary sources of American distrust. In Democracy \& Trust, edited by M. E. Warren. New York: Cambridge University Press, pp. 151-207.

Peters, Guy B. 1999. Institutional Theory in Political Science: The 'New Institutionalism'. London: Pinter.

Putnam, Robert D. 1993. Making Democracy Work: Civic Traditions in Modern Italy. Princeton: Princeton University Press.

Putnam, Robert D. 2000. Bowling Alone: The Collapse and Revival of American Community. New York: Simon \& Schuster.

Putnam, Robert D., ed. 2002. Democracy in Flux: Social Capital in Contemporary societies. New York: Oxford University Press.

Rothstein, Bo, and Jan Teorell. 2005. "What is Quality of Government: A Theory of Impartial Political Institutions." Washington D. C.: Annual Meeting of the American Political Science Association.

Soroka, Stuart, John Helliwell and Richard Johnston. 2006. "Measuing and Modeling Interpersonal Trust," with, in Fiona Kay and Richard Johnston, eds., Diversity, Social Capital and the Welfare State, Vancouver, BC: University of British Columbia Press, pp. 95-132.

Stolle, Dietlind. 2002.“Trusting Strangers-The Concept of Generalized Trust in Perspective.” Österreichische Zeitschrift für Politikwissenschaft 31(4), pp. 397-412.

Stolle, Dietlind. 2001. Clubs and Congregations: The Benefit of Joining Organizations. In Trust in Society, edited by K. S. Cook. New York: Russell Sage Foundation, pp. 202-244.

Tarrow, Sidney. 1996. Making Social Science Work Across Space and Time: A Critical Reflection on Robert Putnam's Making Democracy Work. American Political Science Review 90 (3).

Thelen, Kathleen. 1999. "Historical Institutionalism in Comparative Perspective." Annual Review of Political Science 2:369-404.

Uslaner, Eric. 2002. The Moral Foundation of Trust. New York: Cambridge University Press.

Varese, Federico. 2004. "Mafia Transplantation", in János Kornai, Susan Bo Rothstein and Rose-Ackerman (eds). Creating Social Trust in Post-Socialist Transition (pp148-168). New York: Palgrave/Macmillan

Völker, Beate and Henry Flap. 2001. "Weak Ties as a Liability — the Case of East Germany," in Rationality and Society vol. 13 , no 4 , pp. $397-428$.

Warren, Mark. 2001. Democracy and Association. Princeton: Princeton University Press.

Wollebæck, Dag, and Per Selle. 2002. "Does Participation in Voluntary Associations Contribute to Social Capital? The Impact of Intensity, Scope, and Type." Nonprofit and Voluntary Sector Quarterly 31:32-61.

Woolcook, Michael. 2001. The Place of Social Capital in Understanding Social and Economic Outcomes. ISUMA Canadian Journal of Policy Research 2 (1):11-16

Zak, Paul J., and Stephen Knack. 2001. Trust and Growth. Economic Journal 111 (470):295-321. 
${ }^{1}$ Our argument is certainly not that all forms of "generalized trust" are caused by experiences with and trust in the impartiality and fairness of certain government institutions. There are other important sources that create such social capital, for example the early childhood experiences of trust relationships in one's immediate family (Uslaner 2002). However, we would like to suggest that early childhood influences on trust might be, at least partially, the result of parents' experiences with street-level order institutions as presented above.

${ }^{2}$. For a full description of the data set, see www.worldvaluessurvey.org.

${ }^{3}$ The institute is managed jointly by the Departments of Political Science, Public Administration and Journalism/Mass Communication at Göteborg University. For this project, questions about trust have been added to the five surveys 1996 to 2000 with funding from the Swedish Council for Research in the Humanities and Social Sciences. For information about sampling, response rates, etc. please visit www.som.gu.se or contact som@jmg.gu.se.

${ }^{4}$ The survey component of the ESC project (see http://www.arts.ubc.ca/cresp/outc.htm) is designed to provide information on social networks, well-being, socio-economic status, civic participation, and attitudes toward government policies.

${ }^{5}$ The third wave WVS contains the most complete battery of questions about confidence in a variety of institutions.

${ }^{6}$ The results are confirmed in the WVS aggregate data set.

${ }^{7}$ The survey questions here were phrased with regard to trust in institutions (as opposed to confidence).

${ }^{8}$ Data Source: Third wave of the World Value Survey. For factor scores see Table 1

${ }^{9}$ Graph depicts aggregate changes in generalized trust and trust in the police per country on a percentage scale from 0-100. Data Source: includes the countries of the first and fourth wave of the World Value Survey; whereas changes are calculated between the first and fourth wave of the WVS.

${ }^{10}$ Trust in legal institutions could not chosen because this item was not asked in wave 4 . Therefore trust in the army was dropped as well as the least central indicator of trust in order institutions.

${ }^{11}$ IRIS stands for International Country Risk Guide (ICRG) Data which provides annual values for indicators of the quality of governance, 1982-1997, constructed by Stephen Knack and the IRIS Center, University of Maryland, from monthly ICRG data provided by The PRS Group.

${ }^{12}$ These are not ideal measures of institutional impartiality, yet indicators of police corruption or court corruption are not readily available.

${ }^{13}$ See Delhey and Newton (2004) and Freitag (2006) for a similar approach.

${ }^{14}$ This was calculated by comparing the R-squared of a regression model with institutional efficiency and impartiality measures and a model with these variables and the interaction term, on this procedure see Jaccard (2003).

${ }^{15}$ Descriptive statistics are in the appendix.

${ }^{16}$ This effect is difficult to compare to associational involvement because of their different scales, e.g. being an associational member as compared to not being a member pushes .84 on the 11-point generalized trust scale.

${ }^{17}$ The one point increase on the $0-100$ scale for police rating increases the odds of trust by $6 \%$, and for the rating if government scale by $5 \%$.

${ }^{18}$ Since all three items were included in the second and third wave of the WVS, we utilize both of them here as a cross-sectional data set. The Cronbach's alpha using these three items is alpha=.66. 